\title{
Inheritance and Conflict: A Psycho-Feminist Reading of Alobwed'Epie's What a Next of Kin and Linus T. Asong'sChopchair.
}

\author{
Vivian BongkaTah* \\ Is a Cameroonian who originates from Bui Division in the North West Region of Cameroon.
}

*Corresponding Author: Vivian BongkaTah, Is a Cameroonian who originates from Bui Division in the North West Region of Cameroon.

\begin{abstract}
This paper discusses the paradox of inheritance as presented in Alobwed'Epie's What a Next of Kin and Linus T. Asong's Chopchair from psycho-Feminist standpoints. The psychoanalytic theory enables us to make observation of characters' behavior which serves as a guide to understand human behavior since literature is a reflection of the society. While the Feminist theory shows how women negotiate their identity and also how they respond to patriarchal tendencies. The crux of the problem captured here is that, the conscious needs of characters stimulate defenses that lead to destruction. The understanding of inadequate destructive behavioral patterns will provide platforms for readjustments/resolving conflicts that may pose as barriers and obstacles to the developmental processes of a society. The pertinent question that stirs the mind is what unconscious motives are operational in main characters that contribute to dysfunctions that disrupt social security. This thus leads to the conclusion that insatiable and uncontrollable desires result to dysfunctions that spark conflicts and resistance that may disrupt society's harmony if mind sets are not restructured.
\end{abstract}

Keywords: inheritance; conflict; conscious; unconscious; and destruction.

\section{INTRODUCTION}

Inheritance is an indispensable part of the African cultural system, which is highly coded in patriarchy as it denies the woman her fundamental human right to inherit land and other properties. Traditionally, land and property ownership is passed through a male heir. Emeka E. Ebiola sees succession and inheritance which was established since creation as a process of transferring socioeconomic and political power. This paper addresses the polemics that surrounds succession and inheritance and examines the impacts and consequences of relegating other children in the family to favour a specific child who is considered legitimate heir. It reiterates that inheritance is not only limited to material things but is extended to biology which can spark real fire as seen in Chopchair as Peter Bambe who has been deprived of his birthrights because, sycophants who surround his father the chief, as his advisers naively discard him at birth, because of the need to satisfy his father's egocentric attitude of having a legitimate heir. As Peter grows up, he naturally inherits his father enthusiastic and flaming character traits and becomes a real thorn to the family peace when he realizes the truth about his identity. This paper therefore reveals the complexities that bound succession and inheritance and deconstruct the myth of a legitimate male heir as the texts under study lampoon on the idea of an ideal heir who must be the legitimate and single born son of a father. The paper thus examines both physical and psychological conflicts; and the impacts and consequences of such conflicts on individuals who are rigid on matters concerning issues of succession and inheritance. It further deconstructs inheritance myth by portraying that neither gender nor the condition of birth determine who should be a family heir and encourages equal access to opportunities and issues of succession and inheritance to all children especially those who demonstrate assiduity and are capable of promoting family legacies by sustaining the systematic growth and progress in families such that unity and harmony are promoted and sustained. The paper thus is discussed under the following subtopics: Disillusionment; aggression and family disharmony; and mindsets renaissance.

\section{DiSILLUSIONMENT}

This section highlights the disappointment of characters who have accumulated material wealth yet are disillusioned by their unfulfilled wishes. Mr. Ndi, Alobwed'Epie's character in What a Next of Kin 
and Fuo Akendong II, Linus T. Asong's character in Chopchair are paradoxically traumatized irrespective of their success in accruing wealth. Chopchair opens with Fuo Akendong II phrase thus: "I need a chopchair" (Asong 2010: 2). He is resolutely and desperately in need of a male successor. Mr. Ndi, in What a Next of Kin also expresses the same need as seen in the following: "what is the use of wealth then? How can somebody say he is wealthy if he has no next of kin?" (Alobwed'Epie 2013: 12) Though Mr. Ndi has toiled and accumulated wealth, he sees it as an inconvenience especially if there is no next of kin to inherit the wealth he has toiled for. Both Alobwed'Epie and Linus T. Asong present the complexities surrounding the issue of a legitimate family heir in their respective texts used in this study. The uncontrollable desires of their protagonists to absolutely have next of kin distort their mental functioning and what takes precedent is dead drive as their yearning for destruction is high, corroborating Jane Milton et al.'s view that "Psychoanalysis involves emotionally based learning" (Milton et al. 2004: 6). Alobwed'Epie's Mr. Ndi and Asong's Fuo Akendong II are emotional characters who do not only destroy their happiness together with that of those surrounding them, but are ready to die if they do not sort out their heirs. The controversies around wealth and inheritance are embedded in the ironical results produced. Instead of joy and harmony to take control of individuals and families as bequeathal signifies success, primitive wishes that encompass the 'id' spark crises. This brings to play destructive behavioral patterns as seen through Mr. Ndi and Fuo Akendong who have problems they do not realize which lead to their destruction.

The question that baffles the mind is, must one have an heir before being able to enjoy his hard-earned wealth? Fuo Akendong's insatiable urge for a successor puts his defenses in motion as he will only want to hear want will not aggravate his wounds. This raised sycophant advisers around him who will like only the things he liked and hate those he hates notwithstanding the consequences. Irrespective of the fact that Chief Fuo Akendong has been blessed with many children, girls and boys, he remains worried and sad because he considers his girl children as, "fourteen girls without a Chopchair are fourteen curses. Fourteen wounds. Fourteen daggers pointing at my heart" (Asong 2010: 10). His thought is a dysfunction that risks not destroying only his society, but also himself. His reaction disqualifies his girl children as legitimate heirs, yet he has four sons with his first wife whom he had, "expelled the woman on a slight and doubtful charge of infidelity, had disowned all the four boys who now lived in the palace like strangers" (ibid: 5) Fuo Akendong has everything it takes to be happy: wealth, wives, children and friends, yet his destructive behavior and insatiable quest for a special chopchair makes him desolately desperate as he says: “'If Ngwika does not give me a boy today'... 'I will ask God to give me the next pregnancy let me carry it myself and see whether I will not deliver a boy." (ibid: 10) his arrogance and impatience make him to forget that, it takes both a man and a woman to produce a male child as Leonie McSweeny illustrates in his text entitled: Love and Life; Natural Family Planning. His ignorance and aggressiveness stimulate his defenses as he keeps his repressed, repressed in order to avoid knowing what he cannot handle knowingly through selective perception as Lois Tyson insinuates. He decides to hear and see only what he feels he can handle. That is why he says: "Tell me only what I want to hear...don't tell me that Ngwika has not delivered my Chopchair Nkem"" (ibid: 13). That is why when the messenger came with the news that "Ngwika has delivered two boys..." (ibid: 18), it raises his anger and disappointment because two, cannot inherit a legacy or a throne. Because his advisers know of the devastating consequences that may befall both mother and sons, one of the advisers, Achiebio persuaded the chief thus: "My blood tells me that something is wrong. Let me go to Lemvoah and see for myself. You know these women how they see things and how they say them. It is not possible that God can decide to punish a man like you with two Chopchairs. I will want to see the truth and report it as it is" (ibid: 20). This kind of persuasive and sycophant language twists the truth in order to repress his fears and to please him by letting him hear what he wants to hear. As a result, the advisers set out and convince and persuade both Ngwika and Rosa who just put to birth to switch babies, since Rosa had a girl child. The chief is pleased with the news of his wife giving birth to a boy and a girl, but his happiness is short lived as Peter Nwolefect, his biological son who was switched develops fast and investigates his identity. His discovery sparks both physical and psychological conflicts sparks which disrupt both community and family peace.

Fuo Akendong II is blind to see that inheritance is not only limited to material wealth, but also extends to biological traits. A. BameNsamenang writes the following: 
... development and adjustment are biological processes that require protective attention and guidance. In this sense, the type of human beings children grow up to become depends a great deal on what socialization, especially parental and institutional education, does to their human biology - how these processes mold and channel the biology of human development. The concept of development is rooted in the biology of the individual life cycle.... Development also encompasses the concept of reproduction, in which the origin of an individual from parents is related both to the resemblance of offspring and parent (heredity) and to the observation that species breed true to type. (Nsamenang 2016: 9)

Peter Nwolefect fully inherits the character traits of his father, as he too is very hot tempered and aggressive, confirming Nsamenang's assertion that character trait is hereditary. His parent's negligence to give him protective attention and guidance in is development process has resulted to uncontrollable dysfunction as he does not take things easy when he discovers that he has been deliberately deprived of parental love, the joy and luxuries of his father's palace, and education. His defenses are stimulated to play as he takes it out on his twin brother, Chopchair whom he considers less threatening than his father who has caused his frustration, anger and pain. He kidnaps Chopchair and takes his place in the palace without anyone recognizing the difference. Though he now lives in his father's palace, he is not comfortable as he wrestles with the problem of integrating with life in the palace and to behave as princes do. One thing remains clear as seen below:

He had come to succeed his father, the chief. But when he looked at the man he looked so strong that he did not think he would live long enough in the palace to await his death in order to take over his throne. The man did not look dieable by any means. He wondered whether the easiest way to succeed the old man was not to kill him and become the Chief at once. (ibid: 72)

Peter Nwolefect modes of relating have been structured by lack of parental guidance which has shaped his innate personality and perception of the world negatively. He lacks self- fulfillment because he has been deprived to enjoy life. He is rather a curse than a blessing to his family and community because of the irrational decisions he takes. First, he kidnaps and imprisons his twin brother whom he sees as an obstacle. The above passage reveals his wish for his father's dead, so that he inherits the throne. Since his wish cannot be easily fulfilled because his father still blossoms with life, his thoughts are geared towards eliminating him at once and inheriting the chieftaincy. Though he is now seen as a curse to his family and community, the cause is his father and sycophant counselors who had fail to guide him from birth through a "healthy, happy and productive life" (Nsamenang 2016: 10). This negligence will cost FuoAkendong II, his own life for what he had longed not to hear can no longer be concealed. Dead drive sets in as a result of his self- destructive attitude. His fears and unresolved personal conflicts results to crisis, especially as he cannot tolerate his son Peter Nwolefect's arrogance and untamed behavior which mirrors his, confirming Nsamenang and Akum's assertion in Cross - cultural psychology; An Afrocentric Perspective that, "Genetic inheritance is the transmission of genes or genetic material from parent to offspring. Almost all physical traits, many personality traits and unique abilities are found in the genes, as potentiality (Tchombe et al 2013:16). Peter Nwolefect is a replica of his father as he is hot tempered, bold and courageous as he remains unperturbed when his father shouts. He makes an arrogant request for the division of the kingdom in two equal parts, between his father's chopchair and him. He is not moved irrespective of his father's anger. He is determined to release his brother only after the division of the kingdom. Fuo Akendong II cannot bear and tolerate the consequences of the humiliation in which he finds himself. As a result, he laments thus:

'Death has broken the shoulder on the spot where my bag hangs,' he sighed. 'I will not be party to the nonsense,' he told Nkem-Fuo, 'get in touch with those cut-throats you call Chiefs. Let the leeches come tomorrow morning and cut me up into pieces, let them suck as much as they have always wanted themselves. Let them give the rest to the devil and his disciple.' (Ibid: 92)

Fuo Akendong lives a disillusioned life worrying who will be is next of kin. It becomes paradoxical that the son he envisaged as his next of kin cannot occupy that position as his abandoned and neglected son emerge to claim that position. It is now evident that he has lost what he has spent his whole life protecting. He can no longer bear the humiliation as his pride has been touched. $\mathrm{He}$ 
surrenders the throne to his enemies and is unable to resist living a stressful life as "He died that same night of heart failure!" Mr. Ndi in What a Next of Kin also lives a meaningless and stressful life because he fails to satisfy his desire to get a next of kin. He interrogates thus: "Then what is the use of wealth?'" (Alodwed'Epie 2013: 11), reiterating its nothingness if it cannot give satisfaction and fulfillment. Mr. is not satisfied with his life irrespective of the fact that he has toiled to accumulate wealth. He as a result seeks refuge in death by involving himself in a dreadful accident and while in the hospital, "was starving himself to death" (ibid: 94) because "Ndi was anxiously looking for a next of kin" (ibid: 83). Both Asong's Fuo Akendong and Alobwed'Epie's Mr. Ndi live life in physical pain and agony, and also in a swamp of psychological pain just because they cannot fulfill their wishes of having legitimate next of kin.

\subsection{Aggression and Family Disharmony}

This section portrays how aggressive tendencies disrupt family harmony. Ndi develops a hostile attitude towards his wives and daughters whom he considers the sources of his predicaments. Like FuoAkendong II, he pours his anger and frustration on his immediate family members who constitute women. In the process of transferring his heightened aggression, he suffers trauma which inflicts not only physical and psychological pains on him, but gradually leads him to depression. We read in the text how "A chill ran through him as he thought if he had known that his first wife's witchery would render his future so bleak. He would have killed her when he first suspected that she was responsible for his misfortunes" (Alobwed'Epie 2013: 1). Ndi pours his frustrations on his first wife whom he believes is the cause of his misery as he consults a soothsayer, Fai Nchotu, who tells him that, "Your problem is simple. Your first wife converts your son-bearing sperms into daughter -bearing ones and there is nothing you can do about it..." (ibid: 12). His disappointment leaves him with a heavy heart and he behaves thus:

...he took solace in singing his wailing songs... his first wife brought him his delicacy- groundnuts from home. He eyed with mixed feelings, sighed and abandoned them where she put them... she came in to collect the container... finding it still untouched... she remarked, 'I have observed with disheartening concern that you have generalized your disagreement with your wife... 'shut up you principality of the highest order, devil incarnate, source of my doom...open your curse mouth again and you will go parking to return to your royalty. Open your evil mouth again - shit, beef,' Ndi insulted, took an ominous step toward her and thinking she would be frightened and run away, threw a ferocious slap at her. Poor third wife! She did not expect an onslaught as a recompense for her generosity... it homed in squarely with a deafening bang on her left jaw, causing a couple of teeth to fly out of her mouth...then she fell limply straightforward, the way a scarecrow falls, without struggle... in order not to show cowardice he kicked her a couple of times. The children yelled in disbelief and fright. (ibid: 14-15)

Mr. Ndi sinks in sorrow and despair as it dawns on him that he may never have a legitimate heir to inherit his wealth. His dysfunctional mind evokes hatred for his first wife that makes it difficult for him to accept eating anything from her. As a result, he recompenses her generosity by being both verbally and physically aggressive towards her. His patriarchal attitude could be interpreted as a defense mechanism to project and safeguard his power and authority as a man. Kate Millette in Sexual Politics "condemns Freud as a prime source of patriarchy attitude against which feminists must fight" (Barry 1995: 130). Psychoanalysis, though share a relationship with feminism, is patriarchal because Freud demonstrates male experience as standards to measure female standards. Psychoanalysis through its phallocentric element presents the man as an objective rational and powerful being while relegating the woman to an irrational shadow. Mr. Ndi's psychic is shaped by such a destructive patriarchal attitude, which is central to family disharmony and malfunction. All feminist activities have ultimate goals to change the world by promoting gender equality. Mr. Ndi's third wife plays the role of an activist by demonstrating the importance of sisterhood in women's liberation process as seen below:

The third wife heard the yell and rushed to the scene. 'What are you doing - getting mad?' ... under the spell of years of built in grudges and urge for revenge, gathered every bit of her strength together, and probably assisted by some weird hand seized 
Ndi midway, yanked him upward, spun with him a couple of times and let go, the manner of weight- thrower lets go the weight . Ndi flew in the air a good number of meters away and fell with a thump and remained motionless where he fell. 'You this he-goat, you want to kill an innocent old woman? Come again and touch her you will see me squeeze your breath out of your lungs. Stupid', she threatened and insulted... fearing counterattack, she rushed into the kitchen and took a pestle, then stood guard... over her 'fallen' co-wife waiting for Ndi. She felt an upsurge of concern and regret take possession of her. She exhaled noisily like a deflating balloon and dashed forth to find out why Ndi was not reacting. To her horror she saw the unthinkable.

Ndi's face was frightfully pale and elongated by the impact of the fall; his eyes bulged, and his mouth, wide open, gave the impression of an obscene yawn, or a desired but unrealized appeal for help- unrealized by the sudden loss of memory. The third wife shivered with fright, she had not heard him groan nor asked for help...inflict remarkable hurt on Ndi... Ndi cast a blank beady stare at her like a dead fish....'let's send for an ambulance. He has to be rushed to hospital. His pulse is very low,' Mr. Ndeb said emphatically. (ibid: 15-16)

Mr. Ndi's third wife's action signifies a struggle for better family policies that can protect and guarantee the security of each family member. It highlights that values that could result to growth and progress in the family should be privileged over aggressive tendencies that disrupt family peace and unity. Her action also deconstructs the assertion that a woman is a submissive docile and weak being that could be manipulated upon at anytime by aggressive forces. It further demonstrates that a woman's silence to patriarchal aggression is motivated by respect and that when any individual or group, no matter how weak, is continuously oppressed or exploited by a stronger force, there is the tendency to build grudges that stimulate the urge for revenge that sparks resistance that can destroy either family or societal peace and harmony. Mr. Ndi cannot resist his third wife whom he had least expected such fierce resistance from her. His vulnerability signifies that no man is all powerful and also that, men are susceptible to emotions when confronted with challenges. Therefore, the idea of men being strong and rational and women often referred to as weak and emotional is challenged here.

Though Mr. Ndi is severely hurt and is rushed to the hospital, he does not learn a lesson from his spiteful and dysfunctional behavior. He continues to be verbally aggressive towards his wives and children. His verbosity reveals him as a hysterical irrational being who refuses to learn from his mistakes. He asks his first wife to leave his house before he should return from the hospital. His wives demonstrate the spirit of sisterhood and unity as together with the children, they decide to desert their home if one person must leave. We read in the text thus:

Ndi returned home to an empty house. His third wife had abandoned house before Mr. Ndeb told her of the divorce. In going, she took all her children with her to her maternal brother's house at Tole. Although Ndi had sent word that he did not want to meet her in his house upon his return from hospital, he was ill prepared for the loneliness that greeted him when he got home. Agreed, he hardly pampered his daughters before he was taken to the hospital. But he was used to the noise they made, the running up and down and childish temper that flared up and cooled down with no apparent reasons. All that was now lost. (ibid: 71)

Mr. Ndi has constantly considered and treated his wives as help maids and as companions who must fulfill his desires. Though the women have always found themselves in sentimental exile in their own marital home Ndi still sends them to physical exile without any consideration. Despite the fact that he too finds himself in a state of psychological exile as he is not adequately prepared to embrace the dead silence and loneliness of his once vibrant house that bustle with the noise of his unloved girls, Loomba states that, "across the colonial spectrum, the nation- state or its guiding principles are often imagined literally as a woman" (loomba1998: 215). Ndi's oppressive tendencies towards his wives effectively parody colonial oppression in the nation -state. And the fact that Loomba herself says "Resistance itself is feminized" (idem) substantiates Mr. Ndi's wives resistance, which signifies that state colonialism meets with fierce resistance. Mr. Ndi's unprepared state to cope with the loneliness he creates, signals the predicaments that awaits a disintegrated nation as "the family is both used as a metaphor for the nation" (ibid 217). Therefore, for the family as well as the nation to progress, both 
men and women must experience mindsets renaissance that calls for a complementary order in the face of life's struggle.

\section{Minddets RenaissanCE}

This section expresses the need of individual mindset change from different perspective so as to foster a harmonious environment that can generate peace and prosperity in the society. Characters in both Alobwed'Epie and Asong's texts in context have demonstrated that most African societies as well as other third world countries need renaissance to meet up with the needs and challenges of the ever changing society. Ngugi wa Thiong'o stipulates that, "No renaissance, however, can replicate all aspects of another; but all contain the central idea of rebirth and the spring of new vision of being" ( Ngugi 2009: 88). In the text studied here, it is clear that not only Mr. Ndi and Fuo Akendong II need rebirth of minds but also other characters that precipitate the downfall of the protagonists in one way or the other. A pertinent issue at stake that ruins harmony and peace in most developing societies is the issue of a family heir. Abby Morrow Richardson in his book entitled, Women's Inheritance Rights in Africa: The Need to Integrate Cultural Understanding and Legal Reform write that:

A considerable huddle to the realization of women's human right in Africa is the pervasive denial of a woman's right to inherit land and other property. In many traditional societies in sub-Saharan Africa, land use, housing, and the transfer of land and housing between generations is regulated by customary law, which largely excludes women from property ownership and inheritance (Richardson 2004: 1).

Richardson stresses that succession rights and inheritance which are established procedures of transferring socio-economic and political powers is highly patriarchal because male are privileged and regarded as heir and apparent successors not only as far as land and housing issues are concerned, but also social and economic power. Irrespective of the fast changing traits in present day dynamic and liberalizing society women are greatly marginalized in this domain. Robert Diyanni affirms that, "Psychological criticism approaches a work of literature as a revelation of its authors mind and personality" (Diyanni 1998:1901). Therefore, through the creative imaginations of Alobwed'Epie and Asong, they crave for an ideal society by creating characters whom they use as metaphors to portray their authorial visions.

Psychoanalysis gives an insight to both authors' mental and emotional characteristics; and the literary characters they create. Fuo Akendong's desire for a 'chopchair' to inherit his artistic craft as the following articulates, "Do you Know that if I die without a Chopchair, all this art will die with me?' (Asong 2010: 10) corroborates Freud's psychological mechanisms of "“displacement,' 'condensation,' 'fixation,' and 'manifest and latent' dream content'" (Diyanni 1998: 1901). Fuo Akendong's worry parallel Asong's conscious or unconscious craving for someone to inherit his artistic prowess. He therefore creates a character on whom he does not only displace his unfulfilled wishes, but whom he also uses as a metaphor to express his dream to elevate individual and society's moral standards. Asong's distorted dream is expressed in his novel through the use of symbol as an attempt to discover and explain the meaninglessness of living a stressful life longing for an heir to inherit one's skill, position or property. The predicaments that befall Fuo Akendong is a warning that calls for mindsets readjustments in order to live a meaningful, peaceful, and happy life.

Alobewd'Epie also deconstructs such a destructive mindset that jeopardizes family and society's peace and harmony through Mr. Ndi, his symbolic character, who lives in hopelessness and despair because he is so worried about his future heir. His negative expectancies push him to use words without any rational thought. For example, he says that, “... Nobody goes sowing for birds to eat. Nobody goes sowing on rocky soil. People sow on fertile soil for good harvest. And when the harvesting in done it is stored and protected to feed the farmer's progeny" (Alobwed'Epie 2013: 20). This abusive language refers to his female children whom he sees as birds and rocky soil because he concords with traditional / customary laws to marginalize his female children and to deprive them from the right of inheritance. The allegation he holds against his daughters is thus:

... daughters move compounds when they get married. That likelihood of moving compound is the bedrock on which their rights and prerogatives in their paternal homesteads are determined... and thus a temporary entity in her paternal homestead. A temporary entity cannot be given the rights and prerogatives of next of kin... sons 
by daughters are not good enough to be ones next of kin. They are not, not i, i, ideal,' Ndi stammered in his heart, lamenting his situation.(ibid: 53)

Mr. Ndi's selfishness as the passage above illustrates reflects man's egocentric nature. He prefers to live a miserable life irrespective of all his achievement just because he female children will get married and their husbands will likely enjoy what he has sweated for. In the course of relegating and marginalizing his daughters to whom he refuses the right of next of kin, he also deprives himself from enjoying his hard earned wealth. He toils in misery, looking for a male heir as:

... he concluded that, the only option left for a man with daughters only is to keep looking for a son. A son is the only insurance for the preservation and maintenance of the homestead - a sanctuary whose raison d'etre is the per-foliation of people (the living and the dead) of the same paternal blood. (idem)

Mr. Ndi is not rational in thoughts and actions. He does not solve his problems in an objective manner, but is rather very hysterical. He forgets to know that nature does not work to satisfy the caprices of man. One cannot determine what awaits his tomorrow as nature does not respect the desires of principle. His whimsical attitude makes him to undermine this and thinks that he must look for a 100 percent blood son to ensure and preserve his homestead for posterity. Even though nature does not work to suit man's desires, science has proven that man can determine the desired sex of his baby. That is why Mr. Ndi must stop blaming and attributing his failure on his wives. He must know and accept the truth that, "A woman is a receptacle. Whatever you put in it, it retains. She does not change it of her own prowess. Garbage in, garbage out. All women are capable of son bearing ..." ( ibid 12). If Mr. Ndi strongly desires a male heir as his insurer of continuity then he must do what is required to get a male child. He should know that the sex of a baby is not in any way influenced by the toughness or even gentleness of its father. Rather than bringing in different women whom he cannot satisfy and who cannot also satisfy him and fulfill his wishes, he should submit and educate himself on what will give him appropriate results. Leonie Mc Sweeney writes thus:

The various parts of a child's body including the sexual organs are formed by the union of contributions from husband and wife. A man has a pair of chromosomes called $\mathrm{X}$ and $\mathrm{Y}$. That makes him a man. A woman has a pair called $\mathrm{X}$ and $\mathrm{X}$ (both are X's). The parents both contribute one of the pair to their child. The mother must contribute an egg with an $\mathrm{X}$, because she has no $\mathrm{Y}$. The father contributes either $\mathrm{X}$ or $\mathrm{Y}$. If his $\mathrm{X}$ chromosome captures the egg the result will be $\mathrm{XX}$, a baby girl. If his $\mathrm{Y}$ chromosome enters the egg it will be XY, a baby boy. And so the sex of a baby depends only on the father's contribution. (McSweeney 1982: 98)

The above except discloses Mr. Ndi's ignorance and blindness. He believes that his first wife converts his "son- bearing sperms into daughter- bearing ones and there is nothing he can do about it" ( Alobwed'Epie 2013:12). This kind of superstitious and vicious mindset that tear families apart is deconstructed. The passage above demands that men should have knowledge of how their bodies function biologically, thereby, stop being aggressive and traumatizing their wives, requesting from them what they do not have. A woman can only retain what was put in. If he thinks that he cannot sow on rocky and infertile ground, then he should blame himself for putting garbage in which are his X chromosomes. If he must sow on fertile soil for it to germinate, grow and yield fruit, then he must know how to put in his Y chromosome, which is fertile ground that will produce for him a male heir, the insurer and of continuity of his estate. He therefore needs more knowledge to know when to put in his wife his boy sperms and stop living the life of a scapegoat, when he himself has the solution to his problems.

What Mr. Ndi fails to understand as he searches an heir who will insure and preserve his homestead is that, responsibility cannot be attributed to sex, but on hard work. Society therefore needs to go beyond patriarchy and readjust mindsets such that it does not cling on traditional models to relegate and exclude women both socially and economically. Alobwed'Epie demonstrates through some symbolic female characters like matron Caro and Namondo that:

'Most people who have only daughters nowadays make them inherit their property. The introduction of letters of Administration and the legalization of certificates of next of kin have neutralized the male-based traditional inheritance....' (Alobwed'Epie 2013: 50) 
Perversely patriarchal models program and deprive women of many beneficiary rights. Since feminist critics consider literature as a platform for social transformation, Alobwed'Epie does not only raise feminine consciousness in his novel in context, but deconstructs patriarchal traditional rules that relegate and despise women. Through his female characters, he has demonstrated that the throbbing head ache Mr. Ndi suffers because he has only female children does not worth the pain. He articulates clearly and concisely that if children are given equal opportunities in their upbringing, irrespective of whether they are males or females, the results can be very productive. Matron Caro, though a woman, demonstrates skills and dexterity in the way she manages her affairs. She emerges as a successful woman, and emerges as her father's pride as she takes proper care of him as he advances in age. When her father falls sick, she takes him to a hospital where:

...resuscitating conditions and lodging are better. There is no honour I can give him than to have him admitted in a ward worth less than what I owe him. If there were more expensive ones I would have preferred it. I am his only surviving child. We were four, two boys and two girls. All have died but me. My father is a senior service by any right. He can stake on me on one hand, and on himself on the other hand. He is a no nonsense economic and social power house himself. And so, I, his rightful next of kin, owe him the honour to place him within our combined rights.... (ibid 2324)

Matron Caro makes her father proud and feels fulfilled by giving him appropriate care and attention in spite of her being a female. She shows him love and gives him the honour he deserves for challenging patriarchy and educating her. Though her father was privileged to have two boys, nature which does not respect human desires took them away as they died. Had it been matron Caro's father was also chauvinistic and deprived her of education, he would have not had all the hunour he is now having and his death could even have been precipitated. But when he was educating her, "there was that bullshit talk of his wasting his money on another person's property" (ibid: 51). Such an egocentric mindset needs to be deconstructed, for nature works in ways one cannot adequately tell. Matron Caro is therefore portrayed as " “... knowledgeable and upright ... the lady with the lamp... Two men put together... even doctors respect her. I raise my cap for her"' (ibid: 26). Matron Caro becomes an ideal and exemplary character. She deconstructs the traditional claim that women are weak naturally and puts on the strength of two as reflected in her assiduity. Irrespective of her solid personality,

"Matron Caro has neither looked low nor high on her nature. She has never despised men. She has never also elevated them.... In relation to what we call her prowess, all she did was to improve on her feminine nature and emerge as an icon worthy of emulation." (ibid 48)

Matron Caro remains humble and respectful, not withstanding her high social background, eradicating the fear some men have for women of high social standards. She demonstrates that women too can be successful in whatever they lay their hands on and still be humble. She improves and makes good use of her nature as a woman. Alobwed' Epie writes the following:

Men have always misunderstood and distorted the design of nature. They have even gone as far changing the design of the bible. In the bible it is clearly stated in Mark 10:7-8 'And for this reason a man will leave his father and mother and unite with his wife, and the two will become one, so they are no longer two, but one.' A man will leave his father and mother's homestead for his wife's homestead and the two will unite. That is the design of the bible. But in their greed and usurpation men in interpreting this, have hijacked the supreme position of the woman in marriage. Instead of the man leaving his homestead, he makes the woman leaves hers and so degrades her into a stranger and makes her occupy an inferior position in the union.... (ibid 48)

A woman is supposed to complement a man in marriage. Because men have misunderstood and distorted even the concept of the head of a family they construct laws that marginalize the women. For example people had mocked at Maron Caro's father for education a female child. This is because they thought that he was empowering her to emerge and consequently she might no longer be submissive to men to project their authority. This woman does not only take proper care of her father, 
an assignment tradition reserves for men because the belief is that female children are their husband's properties. Mastron Caro has proven that, that is a distortion, and irrespective of her outstand standing position in the society, she remains loyal to all. What baffles the mind's understanding is the pain some men go through searching for a male child to guarantee their tomorrow just because they think a woman is a temporal entity to their homestead. The above quotation illustrate that men suffer worthlessly because they distorts not only natural designs, but also laws they assume will defend and protect their interests. Even the Bible, as seen above states it out clearly that a man shall leave his parent and join his wife and the two shall become one. It is therefore glaring that the urge for a male heir is a model to usurp the female right through socially constructed laws that disempowered women so as to keep them constantly marginalized. The result is paradoxical as seen through Mr. Ndi and Fuo Akendong who instead of enjoying and celebrating their achievements, live in hopelessness searching for special male children to safeguard their wealth.

Namondo is another icon who demonstrates the prowess of a woman as she single handedly brings up her son successfully. He tells her son the truth when he asks for his father, Joe Ndi , "that he had impregnated me, he pouted and made promises and escaped" (ibid 99). Though Ndi abandons her with pregnancy, she behaves maturely and responsibly keeping the pregnancy and raising the child up without any bias. She does not poison the child's mind about his father's irresponsibility. Instead, she names the child as seen below: "Ngweh, I named you after my father. The name Ngweh means counselor. My father was a counselor in every aspect of the word. He was rich and generous to a fault..." (ibid: 101). Namondo is a woman who lives in optimism. She refuses to harbor the pain and grudges of abandonment and focuses more on positive things that could better shape her life. Even though Ngweh's father has failed her, she still values the men folk as she sees her father as an ideal character worth emulating. She therefore names her son after her father who was a rich, generous and good counselor. By naming her son after her father, she is insinuating that he emulates his ideal qualities. Her moral upbringing of her child makes him to grow "up to be an exemplary boy. You dwarf all your mates and even older fellows who grew up in the guidance of their fathers." (idem) Ngweh though brought up by a woman becomes an ideal character in his society confirming the prowess of a woman.

In spite of the fact that Namondo "had suffered to bring you up without help from anybody" (idem), and irrespective of the fact that Ngweh is successful, when his biological father Ndi request to see him, Namondo demonstrate wisdom and maturity as she tells her son that, "Nobody has ever advised you on how to do your things. So I leave you and your God to take the decision" (idem). Ngweh forgives his father and "he declared him... his rightful heir" (ibid: 104). Ngweh plays the role of counselor to his father. He restructures his fragmented life, and reconciles all his father's wives and children. We read the following in the text:

Ngweh stood up, thank and embraced his father and said to him, 'Papa, you have set fire on my head. I accept to do as you have commissioned me. And I must set to work right away'

The next day, Ngweh went to Douala and got a service transport vehicle and sent it to collect his father's third wife and her daughters from Tole...

Ngweh had mad accommodation easy. He had maintained the first and third wives in the renovated building... a large self- contained chalet for the daughters with the intension of having them together and making them get used to each other... he sent the vehicle to Bamenda to bring the first wife ... he sent for Ndi's first daughter and her children. He then went to Mundoni himself for Debora's daughter.

When everybody was in place, he invited a photographer for a family photograph. (ibid: 137)

Mr. Ndi's mindset has undergone renaissance and he finally discard his perception of a 100 percent male son to be his heir. He makes Ngweh, his abandoned son his heir and assigns him as the head of his family. He assigns him thus: "Bring them together... I give you unequivocal powers... And in this, be blessed that I may be blessed" (ibid: 36). Ngweh proves that he is a veritable counselor. He does everything within his reach and with his father's blessings he succeeds to bring together again Ndi's fragmented and scattered family. He carries on lots of renovation in Ndi's family and in his environment. He demonstrates through his works, words and action that the need for reconciliation and reconstructions of minds in any fragmented family or society is supreme as seen in his following words: 
We have to renovate our minds and bodies in order to slough our old selves so that the people who knew us will be unable to recognize us in words and deeds. We have to be enclosed in the Ndi new spirit as this wall encloses all the buildings in this compound and we also have to extend our hands of fellowship to the outside as we extended in cleaning the ghettos. I know this will not be easy because the causes of our dispersal laid in us pungent seiments of the past - sediments which if we want to express, will definitely turn into bombshells. It is not how far we express our rights and wrongs that matters but how far we can contain them. (139)

The above except is very symbolic and marks the authorial vision. The author uses the conflict that disrupts Ndi's family to illustrate conflicts that often exist and shatter societies. He demonstrates that irrespective of the gravity of problems face by families or societies, there is need for mindset renaissance exhibited by Ndi and members of his family. The cleaning and renovation that takes place is an indication that there is need to renew mindsets by letting go the filthy things, ideologies and differences that spark conflict causing pain and trauma that deprive people to live in peace and harmony in order to enjoy the pleasant and beautiful things life offers. Therefore, Alobwed'Epie sounds a clarion through the predicaments that meet his character and how the embrace the spirit if of reconciliation and unity to build a solid family and society in order to live a harmonious life. The cleaning of the ghettos is significant in that Africa must also stretch hands in a pan African spirit so as to meet the challenges offered from a bigger spectrum so as to stand straight in the global society.

It is evidence as seen in texts used in this paper that not only individuals need mindset renaissance but also institutions. It has been demonstrated in this work how psychoanalytic critics view literature as the exposure of an authors personality and mind. Diyanni further avers that "Psychological critic see literary works as intimately linked with their author's mental and emotional characteristics. (Diyanni 1997: 1901) Therefore, Alobwed'Epie and Asong's works used here do not only express their consciousness and mental world but are symbols that address plaguing issues in their society. Some institutional reforms need to be redressed in order to ensure its smooth functioning and the humanity's wellbeing. We read in the text thus:

Once he heard about making a will, he grew limp and furious. His blood pressure shot up. He knew making a will was tantamount to declaring the next of kin. Who would be his next of kin - his third wife who has 'killed' him, or his eldest daughter who was already married, or any of the other remaining daughters or his first wife, the devil incarnate?

'I shall like to be operated without making a will matron,' he said in a hiccough.

'It is necessary to make a will. We insist on that not because we expect any bad outcome but because it is our routine - normal medical routine.' (Alobwed'Epie: 2013: 18)

It has already been illustrated how Ndi suffers several predicaments because he is in need of a next of kin. He finds himself in a critical situation that needs an operation. Instead of the matron boosting his morals to accept and brave his present challenges that might even cost his life, she aggravates his wounds by asking him to write his will, taking his mind to the issue of a legitimate heir that has ruined his happiness and is almost costing his life. When Ndi hears that he must make a will before the operation can take place, he becomes tense and enraged; his blood pressure gets too high, putting his life at high risk. This notwithstanding the matron keeps insisting and letting him to know that he can make one of his wives or daughters his next of kin, knowing very well that his mind set is already oriented so see his female folk as curses and the sources of his predicament. One begins to wonder as matron insist, claiming that it is a 'normal medical routine' for a patient in such critical condition to make a will, that which is more important at this critical state, the life of a patient or a will? The situation here could be read a satire on trivial institutional policies that entraps rather that protect and safeguard humanity.

Institutional hypocrisy and arrogance is also satirized through authorial vision. The matron ill-treats her patient by being verbally aggressive towards him as seen below:

'Mr. Ndi, you are a dormant volcano. Your inside is black, worse than sin because you are working on fixed orders. There are no fixed orders in the world. You believe 
boys propagate fixed orders better than girls. That is false in as much as there are no fixed orders, there are situations in which girls have performed better in managing the transient orders that are our portions on earth,'

'Matron, what do mean by transient order? Is one's homestead - a sanctuary of the living and the dead, a transient order?' (58)

The matron falls short of expectation because ethics demands that a doctor should be kind and patient towards patients. Instead she is rude and arrogant and throws destructive insults on her patient, reminding him of how transient life is, at this critical moment the patient needs care and better attention. The role of the doctor is to treat his or her patients from their ailment and not to interfere in their personal or family affairs that maybe even be the causes of their ill health. Keith Petrie and Kerry Chamberlain write that, "Hopelessness has been identified as the major variable linking depression to suicidal intent" (Garfield et al. 1983: 458). The matron instead of bringing hope to her patient instead leads him to a hopeless state as, "the matron and Ndi had been playing a cat and mouse game for about a week, she skipped his room and only assigned nurses to talk to him and help him in case he needed help. That isolation un-nerved Ndi (ibid: 33). The matron and Ndi could be read as symbolic character the author use to satirize the encounter between people in state and private intuitions. There is therefore the crave for a benign relationship between people that would bring peace and tranquility that will lead to growth, rather arrogance and aggressiveness that will lead to hopelessness and conflict that would rather promote stagnation and backwardness in the society especially in today's highly competitive world.

\section{CONClusion}

This paper has demonstrated how wealth paradoxically generates conflicts in individuals and communities. The paper which is structured thus: Disillusionment; aggression and family disharmony; and mindsets renaissance, has illustrated using Alobwed'Epie's What a Next of Kin and Asong's Chopchair that an inadequate understanding of destructive behavioral patterns may pose as barriers and obstacles to the progress of a society. The paper highlights that if insatiable and uncontrollable desires that may result to dysfunctions are not checked, then conflicts that could disrupt both family and society's harmony may be sparked. The paper as a result concludes that conflicts, dysfunctional, and aggressive behavioral standards meet with a powerful resisting force that can stagnate or draw a society backward. The consequences of such destructive patterns can be very overwhelming in today's competitive society where the weak and the poor are constantly exploited. The need for mindsets renaissance is recommended both at the family and institutional levels in order to construct a peaceful society that paves way for growth. Africa and other developing nations also need to restructure their policies such that peace reigns in their societies, paving way for growth that can enable them meet up with the challenges of a global society. Alobwed'Epie in his text upholds this vision as he says: We have to renovate our minds and bodies in order to slough our old selves so that the people who knew us will be unable to recognize us in words and deed" (ibid: 139). This clarion call for reconciliation and mindsets change which is demonstrated through the family is a call for Africa and other developing countries to abandon destructive ideologies and differences in order to renovate their identities such that they meet the needs of a competitivew global society.

\section{REFERENCES}

[1] Alobwed'Epie. What a Next of Kin. Kansas: Miraclaire, 2013.

[2] Asong, T. Linus. Chopchair. Bamenda: Patron, 2010.

[3] Barry, Peter. Beginning Theory: An Introduction to Literary and Cultural Theory. Oxford: Manchester, 1995.

[4] DiYanni, Robert. Literature: Reading Fiction, Poetry, Drama, and the Essay. Boston: McGraw-Hill, 1998.

[5] Keith, P. and Kerry C. "Hopelessness and Social Desirability as Moderator Variables in Predicting Suicidal Behavior," Journal of Consulting and Clinical Psychology. Vol. 51. American Psychological Association, no. 4, 1983.

[6] McSweeney, Léonie. Love and Life: Natural Family Planning. Ibandan: African University Press, 1982.

[7] Milton, Jane et al. A short Introduction to Psychoanalysis. London: SAGE Publication, 2004. Bamenda: HDRC, 2016. 
Inheritance and Conflict: A Psycho-Feminist Reading of Alobwed'Epie's What a Next of Kin and Linus T. Asong'sChopchair.

[8] Nsamenang, Bame. The Developmental Psychology of Human Diversity. Bamenda: HDRC Publications, 2016.

[9] Richardson, Morrow Abby. Women's Inheritance Right in Africa: The Need to Integrate Cultural Understanding and Legal Reform. Washington: Digital Commons @ American University College of Law: 2004. Emeka E Obiola ED.

[10] Nsamenang, A. Bame and Rita A. Akum. "Cultures in the Biology of Human Development" CrossCultural Psychology: An Africentric Perspective. Tchombe, M.S. Therese et al. EDs. Limbe: Design House, 2013.

[11] Tyson, Lois. Critical Theory Today: A User Friendly Guide. New York: Garland, 1999.

[12] Wa Thiong'o, Ngugi. Something Torn and New: An African Renaissance. New York: Civitas, 2009.

\section{AUTHOR'S BIOGRAPHY}

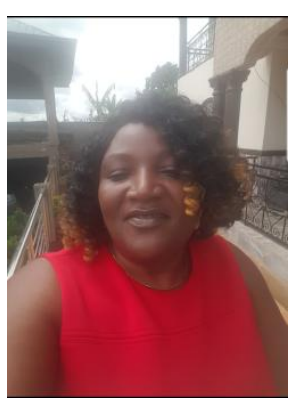

Vivian BongkaTah, is a Cameroonian who originates from Bui Division in the North West Region of Cameroon. She schooled in the University of Yaounde where she obtained a $\mathrm{PhD}$, specializing in Commonwealth/ Postcolonial studies. She has taught in some private universities in Bamenda and currently lectures in the Department of Bilingual Letters of the University of Bamenda, Cameroon. She has published article in national and international peer reviewed journals.

Citation: Vivian BongkaTah. "Inheritance and Conflict: A Psycho-Feminist Reading of Alobwed'Epie's What a Next of Kin and Linus T. Asong'sChopchair." International Journal of Humanities Social Sciences and Education (IJHSSE), vol 8, no. 2, 2021, pp. 204-215. doi: https://doi.org/10.20431/2349-0381.0802021.

Copyright: (C) 2021 Authors. This is an open-access article distributed under the terms of the Creative Commons Attribution License, which permits unrestricted use, distribution, and reproduction in any medium, provided the original author and source are credited. 